\title{
PENERAPAN METODE PENGENDALIAN KUALITAS MEWMA BERDASARKAN ARL DENGAN PENDEKATAN RANTAI MARKOV (Studi Kasus: Batik Semarang 16, Meteseh)
}

\author{
Enggartya Andini ${ }^{1}$, Sudarno ${ }^{2}$, Rita Rahmawati ${ }^{3}$ \\ 1,2,3 Departemen Statistika, Fakultas Sains dan Matematika, Universitas Diponegoro \\ e-mail: enggartyaa27@gmail.com
}

\begin{abstract}
An industrial company requires quality control to maintain quality consistency from the production results so that it is able to compete with other companies in the world market. In the industrial sector, most processes are influenced by more than one quality characteris tic. One tool that can be used to control more than one quality characteris tic is the Multivariate Exponentially Weighted Moving Average (MEWMA) control chart. The graph is used to determine whether the process has been controlled or not, if the process is not yet controlled, thenext analysis that can be used is to use the Average Run Length (ARL) with the Markov Chain approach. The markov chain is the chance of today's event is only influenced by yesterday's incident, in this case the chance of the incident in question is the incident in getting a sampel of data on the production process of batik cloth to get a product that is in accordance with the company standards. ARL is the average number of s ample points drawn before a point indicates an uncontrollable state. In this study, 60 sample data were used which consisted of three quality characteris tics, namely the length of the cloth, the width of the cloth, and the time of the fabric for the production of written batik in Batik Semarang 16 Metes eh. Based on the results and discussion that has been done, the MEWMA controller chart us es the $\lambda$ weighting which is determined using trial and error. MEWMA control chart can not be said to be stable and controlled with $\lambda=0.6$, after calculating, the value is obtained Upper Control Limit (BKA) of 11.3864 and Lower Control Limit (BKB) of 0. It is known that from 60 data samples there is $a T_{j}{ }^{2}$ value that comes out from the upper control limit (BKA) where the amount of 15.70871, which indicates the production process is not controlled statistically. Improvements to the MEWMA controller chart can be done based on the ARL with the Markov Chain approach. In this final project, the ARL value used is 200, the magnitude of the process shift is 1.7 and the r value is 0.28 , where the value of $r$ is a constant obtained on the r parameter graph. The optimal MEWMA control chart based on ARL with the Markov Chain approach can be said to be stable and controlled if there is no $T_{j}{ }^{2}$ value that is outside the upper control limit (BKA). The results of the MEWMA control chart based on the ARL with the Markov Chain approach show that the process is not statistically capable because the $\mathrm{MC}_{\mathrm{pm}}$ value is 0.516797 and the $\mathrm{MC}_{\mathrm{pmk}}$ value is 0.437807 , the value indicates a process capability index value of less than 1 .
\end{abstract}

Keywords: Handmade batik, Multivariate Exponentially Weighted Moving Average (MEWMA), Average Run Length (ARL), Capability process.

\section{PENDAhULUAN}

Batik merupakan salah satu warisan budaya Indonesia yang diakui UNESCO sejak tahun 2009. Nilai estetik dan nilai simbolis yang tinggi menjadi salah satu daya tarik kain batik. Pada zaman dahulu kain batik hanya dipakai pada acara formal saja. Namun saat ini kain batik mulai digemari masyarakat Indonesia di berbagai kalangan, kain batik mulai dikenakan pada acara formal maupun non formal. Makin tinggi minat masyarakat dalam menggunakan kain batik sejalan dengan makin bertambahnya industri batik di Indonesia, salah satunya Batik Semarang 16, Meteseh. Kualitas hasil produksi menjadi salah satu faktor dasar keputusan konsumen dalam memilih suatu produk. Konsumen akan merasa puas apabila produk yang dibeli sesuai dengan keinginan dan harapannya. Hal ini penting untuk menjaga image dari perusahaan tersebut. Selain itu, diharapkan volume penjualan akan semakin meningkat pula. Dengan demikian, kualitas adalah faktor kunci yang dapat membawa keberhasilan suatu bisnis.

Pengendalian kualitas sangat dibutuhkan dalam proses produksi guna menjaga kestabilan suatu produk. Selain harus memenuhi standar yang telah ditetapkan, suatu produk 
juga harus memenuhi syarat untuk digunakan oleh konsumen nantinya. Untuk itu perlu adanya aplikasi ilmu statistika yang berguna dalam menjawab permasalahan kualitas produksi, yaitu pengendalian kualitas statistik (StatisticalQuality Control). Salah satu teknik pengendalian kualitas statistik adalah grafik pengendali (control chart). Grafik pengendali digunakan untuk mengetahui sebuah proses produksi berjalan dalam kondisi terkontrol atau tidak. Sebuah proses yang cukup stabil namun berjalan di luar batas yang diharapkan, harus diperbaiki untuk menemukan akar penyebabnya guna mendapatkan hasil perbaikan yang maksimal.

Grafik pengendali multivariat digunakan untuk dua atau lebih karakteristik kualitas, dengan adanya korelasi antar karakteristik kualitas. Grafik pengendali Multivariate Exponentially Weighted Moving Average (MEWMA) merupakan grafik pengendali multivariat yang mengakumulasikan informasi yang didapatkan dari masa lampau, sehingga lebih sensitif untuk mendeteksi pergeseran proses yang lebih kecil. Average Run Length (ARL) adalah jumlah rata-rata atau sampel yang harus digambarkan sebelum sebuah titik atau sampel menunjukkan suatu keadaan tidak terkendali (Montgomery, 2009). Suatu pendekatan untuk menduga nilai Average Run Length (ARL) dari grafik MEWMA diberikan oleh Runger dan Prabhu (1996). Runger dan Prabhu (1996) menggunakan pendekatan rantai Markov untuk menduga nilai Average Run Length (ARL) grafik pengendali MEWMA.

Tujuan dari penelitian ini adalah menerapkan grafik pengendali MEWMA serta menerapkan ARL dengan pendekatan Rantai Markov pada grafik MEWMA yang tidak terkendali pada proses produksi batik tulis di Batik Semarang 16, Meteseh. Untuk menghitung kemampuan proses dalam memenuhi standar batas-batas spesifikasi kualitas batik tulis di Batik Semarang 16, Meteseh.

\section{TINJAUAN PUSTAKA}

\subsection{Pengendalian Kualitas (Quality Control)}

Pengendalian Kualitas ialah cara organisasi menerapkan produk-produk manajemen kualitas secara konsisten untuk memenuhi kebutuhan pelanggan dan pasar (Gaspersz, 2005). Pengendalian kualitas merupakan upaya mengurangi kerugian-kerugian akibat produk rusak dan banyaknya sisa produk atau scrap. Pengendalian mutu adalah suatu aktivitas keteknikan dan manajemen sehingga ciri-ciri kualitas (mutu) dapat diukur dan dibandingkan dengan spesifikasinya (standar). Kemudian dapat diambil tindakan perbaikan yang sesuai apabila terdapat perbedaan atau penyimpangan antara penampilan yang sebenarnya dengan standar.

\subsection{Uji Normalitas Multivariat}

Salah satu asumsi yang harus dipenuhi untuk melakukan pengendalian kualitas menggunakan grafik pengendali multivariat adalah data berdistribusi normal multivariat. Distribusi normal multivariat merupakan suatu perluasan dari distribusi normal univariat untuk dimensi $\mathrm{p} \geq 2$ dengan variabel-variabel yang dependen (Johnson \& Winchern, 2007). Variabel $\boldsymbol{X}=\left(X_{1}, X_{2}, \ldots, X_{p}\right)$ dikatakan berdistribusi normal multivariat dengan parameter $\boldsymbol{\mu}$ dan $\boldsymbol{\Sigma}$ jika mempunyai fungsi kepadatan peluang sebagai berikut:

$$
f(\boldsymbol{x})=\frac{1}{(2 \pi)^{p / 2}|\boldsymbol{\Sigma}|^{1 / 2}} e^{-\frac{1}{2}(\boldsymbol{x}-\boldsymbol{\mu})^{\prime} \boldsymbol{\Sigma}^{-1}(\boldsymbol{x}-\boldsymbol{\mu})}
$$

Adapun prosedur dalam pengujian distribusi normal multivariat yang akan dilakukan, yaitu dengan membuat $q-q$ plot dengan tahapan pertama menentukan nilai vektor rata-rata dan matriks varian kovarian. Kemudian menentukan nilai jarak Mahalanobis setiap titik pengamatan dengan vektor rata-ratanya dengan persamaan $d_{j}^{2}=\left(\boldsymbol{x}_{\boldsymbol{j}}-\overline{\boldsymbol{x}}\right)^{\prime} \boldsymbol{S}^{-\mathbf{1}}\left(\boldsymbol{x}_{\boldsymbol{j}}-\overline{\boldsymbol{x}}\right)$. Setelah nilai $d_{j}^{2}$ diperoleh, urutkan nilai $d_{j}^{2}$ dari kecil ke besar. Menentukan nilai $\mathrm{q}_{\mathrm{j}}$ dengan persamaan berikut: 


$$
q_{j}\left(P_{j}\right)=\chi_{p}^{2}\left(\frac{j-0.5}{n}\right)
$$

Dimana nilai $P_{j}=\frac{j-\frac{1}{2}}{n}, j=1,2, \ldots, \mathrm{n}$

Selanjutnya buat scatterplot $\mathrm{d}_{\mathrm{j}}^{2}$ dengan $\mathrm{q}_{\mathrm{j}}$. Jika scatterplot ini cenderung membentuk garis lurus dan sekitar $\geq 50 \%$ nilai $\mathrm{d}_{\mathrm{j}}{ }^{2} \leq \chi_{p ; 0,50}^{2}$ maka dapat dikatakan bahwa data berdistribusi normal multivariat.

\subsection{Uji Signifikansi Korelasi}

Variabel $x_{1}, x_{2}, \ldots, x_{p}$ dikatakan saling bebas jika matriks korelasi antar variabel membentuk matriks identitas (Morrison, 1990).

Hipotesis

$\mathrm{H}_{0}: \mathbf{R}=\mathbf{I}$ (tidak ada korelasi antar variabel)

$\mathrm{H}_{1}: \mathbf{R} \neq \mathbf{I}$ (ada korelasi antar variabel)

Statistik Uji:

$$
\chi_{\text {hitung }}^{2}=-\left\{n-1-\frac{2 p+5}{6}\right\} \ln |\boldsymbol{R}|
$$

Sehingga keputusan menerima $\mathrm{H}_{0}$ yang berarti antar variabel bersifat saling bebas, jika nilai $\chi_{\text {hitung }}^{2} \geq \chi_{\left(\alpha, \frac{1}{2} p(p-1)\right)}^{2}$, dengan $n$ merupakan banyaknya observasi, $p$ adalah banyaknya karakteristik, dan $\mathbf{R}$ adalah matriks korelasi dari masing-masing variabel.

\subsection{Multivariate Exponentially Weighted Moving average (MEWMA)}

Grafik pengendali MEWMA merupakan pengembangan dari grafik pengendali EWMA yang digunakan untuk mendeteksi terjadinya mean proses yang kecil secara multivariat. Kelebihan grafik pengendali MEWMA adalah robust terhadap asumsi distribusi normal, sehingga ketika data tidak memenuhi asumsi normal maka grafik pengendali ini masih bisa digunakan (Montgomery, 2009). Berikut adalah vektor observasi pada grafik pengendali MEWMA

$$
\mathbf{Z}_{\mathbf{j}}=\lambda \mathbf{X}_{\mathbf{j}}+(1-\lambda) \mathbf{Z}_{\mathbf{j}-\mathbf{1}}
$$

Dimana nilai $0 \leq \lambda \leq 1, j=1,2, \ldots, n$

$\mathbf{Z}_{0} \quad$ : vektor 0 dan berukuran px1

$\mathbf{Z}_{\mathbf{j}-1} \quad$ : vektor berukuran px1

$\lambda \quad$ : besarnya pembobot

$\mathbf{X}_{\mathbf{j}} \quad$ : vektor sampel pengamatan ke-j dengan $\mathrm{j}$ yang berdistribusi normal multivariat

Data yang akan diplotkan pada grafik pengendali adalah sebagai berikut:

$$
T_{j}^{2}=\boldsymbol{Z}_{j}^{T} \boldsymbol{\Sigma}_{Z j}^{-1} \mathbf{Z}_{\mathbf{j}}
$$

Dimana matriks varian dan kovarian sebagai berikut:

$$
\boldsymbol{\Sigma}_{\mathrm{Zj}}=\frac{\lambda}{2-\lambda}\left[1-(1-\lambda)^{2 \mathrm{j}}\right] \boldsymbol{\Sigma}
$$

Dengan $\boldsymbol{\Sigma}$ merupakan matriks varian kovarian dari data. Batas Kendali Atas dalam grafik pengendali MEWMA dinyatakan dalam BKA. Nilai BKA diperoleh berdasarkan nilai pembobot $\lambda$ yang telah ditentukan. Proses dikatakan terkendali apabila nilai pengamatan lebih kecil dari batas kendali atau $\mathrm{T}_{\mathrm{j}}^{2}>\mathrm{BKA}$.

\subsection{Average Run Length (ARL) dengan pendekatan Rantai Markov}

Tujuan utama dari grafik pengendali proses statistik adalah untuk mendeteksi pergeseran proses secepat mungkin ketika proses tidak terkendali. Salah satu caranya adalah melalui Average Run Length (ARL). Grafik pengendali ARL adalah rata-rata banyaknya titik sampel yang digambarkan sebelum satu titik menunjukkan keadaan tidak terkendali. 
On target ARL merupakan rata-rata banyaknya titik sampel yang digambarkan sebelum satu titik menunjukkan keadaan tidak terkendali pada proses yang terkendali. Nilai on target ARL ini biasanya ditetapkan oleh perusahaan dan pada penelitian tugas akhir ini on target ARL yang digunakan mengikuti rekomendasi dari Runger dan Prabhu (1996) yaitu sebanyak 200. $\mathrm{ARL}_{0}$ merupakan ARL pada saat rata-rata proses terkendali atau in contro lyang dirumuskan dengan persamaan:

$$
\mathrm{ARL}=\frac{1}{\alpha}
$$

dengan $\alpha$ adalah probabilitas titik melebihi batas pengendali. Sehingga untuk ARL $=200$ berarti $\alpha=0,005=0,5 \%$. Artinya, apabila proses dalam keadaan terkendali, diharapkan tanda tak terkendadli akan dihasilkan rata-rata setiap 200 sampel.

Menurut Ross (2007), proses Markov adalah suatu proses stokastik $\left\{X_{t}, t=0,1,2, \ldots\right\}$ . Nilai yang mungkin dari $X_{t}$ adalah terhingga atau terhitung. Apabila $X_{t}=i$, maka proses dikatakan berada pada state- $i$. Apabila proses berada pada state-i maka akan berpindah ke state-j dengan peluang $\mathrm{P}_{i j}$, di mana $P_{i j}$ tidak tergantung pada $t$. Dengan perkataan lain, apabila:

$$
\begin{aligned}
P\left\{X_{\mathrm{t}+1}\right. & \left.=\mathrm{j} \mid X_{\mathrm{t}}=i, X_{\mathrm{t}-1}=i_{\mathrm{t}-1}, \ldots, X_{1}=i_{1}, X_{0}=i_{0}\right\} \\
& =P\left\{X_{\mathrm{t}+1}=\mathrm{j} \mid X_{\mathrm{t}}=i\right\}=P_{i j}
\end{aligned}
$$

Untuk semua state $i_{0}, i_{1}, \ldots, i_{t-1}, i, j$, dan semua $t \geq 0$, maka proses stokastik tersebut disebut Stasioner Markov Chain.

Dari Persamaan (7) dapat diinterpretasikan bahwa: untuk suatu rantai Markov, peluang kejadian yang akan datang $X_{t+1}$, hanya tergantung pada kejadian sekarang $X_{t}$. Hal ini disebut sifat Markovian. Sifat Markovian ini menyatakan bahwa peluang dari "keadaan" mendatang, dengan syarat "keadaan" masa lampau, dan state saat ini $X_{t}=i$, adalah independent terhadap kejadian di waktu lalu dan hanya tergantung pada keadaan saat ini. Sehingga hal-hal yang dapat diambil pada rantai Markov adalah:

1. Peluang kejadian hari ini hanya dipengaruhi oleh kejadian kemarin.

2. Setiap kejadian dianggap dalam kondisi yang sama atau homogen.

3. Sampel ke 2 dipengaruhi oleh sampel ke 1 . Sampel ke 10 hanya dipengaruhi oleh sampel ke 9.

4. Kesimpulannya semua sampel dianggap dalam kondisi yang sama/homogen.

\subsection{Menentukan Pergeseran Proses}

Sebuah grafik menunjukkan tanda di luar kendali ketika statistik grafik $T_{j}^{2}>H(B K A)$. Perfoma dari sebuah grafik pengendali tergantung pada nilai pergeseran proses yang terjadi. Besarnya nilai pergeseran untuk grafik pengendali MEWMA dilambangkan dengan $\delta$ dan dirumuskan sebagai berikut:

$$
\delta=\sqrt{\left(\boldsymbol{\mu}_{\mathbf{1}}-\boldsymbol{\mu}_{\mathbf{0}}\right)^{\prime} \boldsymbol{\Sigma}^{-1}\left(\boldsymbol{\mu}_{\mathbf{1}}-\boldsymbol{\mu}_{\mathbf{0}}\right)}
$$

Jika $\mathrm{x}_{1}, \mathrm{x}_{2}, \ldots \mathrm{x}_{\mathrm{n}}$ merupakan sampel random dari populasi normal, maka besarnya pergeseran atau rata-rata yang mengalami pergeseran yang memungkinkan atau yang masih dapat diterima $\left(\boldsymbol{\mu}_{\mathbf{1}}\right)$ merupakan interval konfidensi dari distribusi Student's $t$ dengan derajat bebas $\mathrm{n}-1$, yaitu $\boldsymbol{\mu}_{1}$ berada pada interval konfidensi $100(1-\alpha) \%, \boldsymbol{\mu}_{0} \pm \mathrm{t}_{\mathrm{n}-1(\alpha / 2)} \frac{s}{\sqrt{n}}$ yang ekuivalen dengan persamaan berikut:

$$
\boldsymbol{\mu}_{0}-\mathrm{t}_{\mathrm{n}-1((\alpha / 2)} \frac{s}{\sqrt{n}} \leq \boldsymbol{\mu}_{1} \leq \boldsymbol{\mu}_{0}+\mathrm{t}_{\mathrm{n}-1((\alpha / 2)} \frac{s}{\sqrt{n}}
$$

dimana $\boldsymbol{\mu}_{\mathbf{0}}$ merupakan rata-rata proses yang dirumuskan dengan $\boldsymbol{\mu}_{\mathbf{0}}=\frac{1}{n} \sum_{j=1}^{n} X_{j}$, dan $\mathrm{s}$ adalah standar deviasi proses dengan $s^{2}=\frac{1}{n-1} \sum_{j=1}^{n}\left(X_{j}-\boldsymbol{\mu}_{\mathbf{0}}\right)^{2}$. Interval konfidensi tersebut 
memuat semua nilai $\boldsymbol{\mu}_{1}$ yang dapat diterima pada suatu proses dengan tingkat signifikansi sebesar $\alpha$.

\subsection{Desain Grafik Pengendali MEWMA Optimal}

Pemilihan parameter dari grafik pengendali MEWMA menggunakan rantai Markov bertujuan untuk mendapatkan grafik pengendali MEWMA yang optimal. Penentuan parameter grafik, yaitu $\mathrm{r}$ dan $\mathrm{H}$ yang optimal untuk grafik MEWMA dapat dilakukan mengikuti langkah-langkah berikut:

1. Menentukan on target ARL.

2. Menentukan pergeseran $(\delta)$.

3. Menentukan nilai $r$ yang berdasarkan ARL pada langkah 1 untuk nilai pergeseran yang sudah didapatkan. Nilai $\mathrm{r}$ diperoleh berdasarkan grafik optimal parameter $\mathrm{r}$ (Lee dan Khoo, 2005).

4. Berdasarkan nilai optimal $\mathrm{r}$ pada langkah 3, ditentukan nilai $\mathrm{H}$ yang memenuhi on target ARL pada langkah 1.

\subsection{Analisis Kapabilitas Proses}

Kapabilitas proses merupakan suatu pengukuran yang digunakan untuk mengevaluasi keseluruhan proses. Multivariate Proses Capability Indices (MPCI) menunjukkan seberapa baik sebuah proses manufaktur dapat mememui batas spesifikasi ketika karakteristik kualitas memiliki korelasi. Suatu proses produksi berjalan secara capable apabila nilai $\mathrm{C}_{\mathrm{pm}} \geq 1$. Perhitungan indeks $\mathrm{C}_{\mathrm{pm}}$ dan $\mathrm{C}_{\mathrm{pmk}}$ untuk data univariat adalah:

$$
\begin{aligned}
& \mathrm{C}_{\mathrm{pm}}\left(\mathrm{X}_{\mathrm{i}}\right)=\frac{U S L_{X i}-L S L_{X i}}{\sqrt[6]{\sigma_{X i}^{2}+(\boldsymbol{\mu} x i-T x i)^{2}}} \\
& \mathrm{C}_{\mathrm{pmk}}\left(\mathrm{X}_{\mathrm{i}}\right)=\min \left\{\frac{U S L_{X i}-\boldsymbol{\mu} X i}{\sqrt[3]{\sigma_{X i}^{2}+(\boldsymbol{\mu} x i-T x i)^{2}}}, \frac{\boldsymbol{\mu} X i-L S L_{X i}}{\sqrt[3]{\sigma_{X i}^{2}+(\boldsymbol{\mu} x i-T X i)^{2}}}\right\}
\end{aligned}
$$

Keterangan:

USL = batas spesifikasi atas

LSL = batas spesifikasi bawah

Dalam penelitian ini terdapat tiga karakteristik kualitas sehingga indeks kapabilitas yang cocok digunakan dalam kasus ini adalah indeks kapabilitas multivariat. Adapun perhitungan indeks kapabilitasnya sebagai berikut:

$$
\begin{aligned}
& M C_{p m}=\sum_{i=1}^{p} W_{i} C_{p m}\left(X_{i}\right) \\
& M C_{p m k}=\sum_{i=1}^{p} W_{i} C_{p m k}\left(X_{i}\right)
\end{aligned}
$$

dimana $\mathrm{MC}_{\mathrm{pm}}, \mathrm{MC}_{\mathrm{pmk}}$ berturut-turut merupakan $\mathrm{C}_{\mathrm{pm}}, \mathrm{C}_{\mathrm{pmk}}$ multivariat dengan Wi merupakan pembobot berdasarkan kepentingan dengan $\sum_{i=1}^{p} W_{i}=1$ (Raissi,2009).

\section{METODE PENELITIAN}

\subsection{Jenis dan Sumber Data}

Jenis data yang digunakan dalam penelitian ini berupa data sekunder yang diperoleh dari Batik Semarang 16, Meteseh. Data yang digunakan merupakan parameter kualitas kain batik tulis berupa Panjang kain, lebar kain serta waktu pelorotan kain yang diambil pada 9 Februari 2019 hingga 27 Februari 2019. 


\subsection{Variabel Penelitian}

Data yang digunakan dalam penulisan tugas akhir ini adalah data karakteristik kualita s kain batik tulis di Batik Semarang 16 yang berupa data pengukuran atau kontinu dengan variabel penelitian sebagai berikut:

$\mathrm{X}_{1}$ : Panjang Kain

$\mathrm{X}_{2}$ : Lebar Kain

$\mathrm{X}_{3}$ : Waktu Pelorotan Kain

\subsection{Langkah-langkah Penelitian}

1. Menginput data sekunder yaitu data sampel pengukuran panjang, lebar serta waktu pelorotan lilin pada kain pada periode 9 Februari 2019 hingga 27 Februari 2019.

2. Melakukan analisis deskriptif data parameter kualitas kain batik tulis di Batik Semarang 16.

3. Melakukan pengujian distribusi normal multivariat terhadap parameter kualitas batik tulis

4. Melakukan pengujian korelasi terhadap parameter kualitas batik tulis.

5. Menstandarisasikan data sesuai dengan z-score.

6. Membuat grafik pengendali MEWMA sebagai berikut:

a. Menentukan nilai pembobot.

b. Menghitung vektor MEWMA, $\mathbf{Z}_{\mathbf{j}}$.

c. Menghitung matriks varian kovarian berdasarkan $\mathrm{Z}_{\mathrm{j}}$.

d. Menghitung nilai statistik $T_{j}^{2}$ pada setiap pengamatan.

e. Menghitung BKA.

f. Membuat plot $T_{j}^{2}$ dengan batas kendali dari nilai pembobot yang telah ditentukan.

7. Melakukan perhitungan nilai on target Average Run Length (ARL).

8. Menentukan pergeseran $(\delta)$.

9. Menentukan nilai $r$ berdasarkan nilai on target ARL.

10. Menentukan nilai $H$ berdasarkan nilai optimal $r$ yang memenuhi on target ARL.

11. Melakukan perhitungan kapabilitas proses.

12. Membuat kesimpulan berdasarkan metode yang digunakan.

\section{HASIL DAN PEMBAHASAN}

\subsection{Deskripsi Data}

Sebelum melakukan analisis pengendalian kualitas proses produksi batik tulis di Batik Semarang 16, Meteseh terlebih dahulu perlu untuk mengetahui karakteristik dari variabelvariabel yang diamati. Variabel-variabelnya adalah panjang kain $\left(\mathrm{X}_{1}\right)$, lebar kain $\left(\mathrm{X}_{2}\right)$, dan waktu pelorotan kain $\left(\mathrm{X}_{3}\right)$. Deskripsi karakteristik kualitas batik tulis disajikan pada Tabel 1 berikut ini.

Tabel 1. Deskripsi Karakteristik Kualitas

\begin{tabular}{cccc}
\hline Variabel & Mean & Varian & Simpangan Baku \\
\hline $\mathrm{X}_{1}$ & 221,0692 & 10,6528 & 3,2639 \\
$\mathrm{X}_{2}$ & 126,1633 & 1,3969 & 1,1819 \\
$\mathrm{X}_{3}$ & 9,6598 & 0,3081 & 0,5551 \\
\hline
\end{tabular}

\subsection{Uji Normalitas Multivariat}

Salah satu asumsi yang harus dipenuhi untuk melakukan pengendalian kualitas menggunakan grafik pengendali multivariat dan analisis kapabilitas adalah data berdistribusi 
normal multivariat. Dengan menghitung nilai $d_{j}^{2}$ dengan persamaan $d_{j}^{2}=\left(\boldsymbol{x}_{\boldsymbol{j}}-\right.$ $\overline{\boldsymbol{x}})^{\prime} \boldsymbol{S}^{-\mathbf{1}}\left(\boldsymbol{x}_{\boldsymbol{j}}-\overline{\boldsymbol{x}}\right)$, kemudian dibandingkan dengan $\chi_{3 ; 0,50}^{2}=2,366$, diperoleh tabel sebagai berikut,

Tabel 2. Hasil perhitungan nilai $d_{j}^{2}$

\begin{tabular}{cccc}
\hline $\mathrm{j}$ & $\mathrm{d}_{\mathrm{j}}{ }^{2}$ & $\chi_{3 ; 0,50}$ & Keterangan \\
\hline 1 & 1,977 & 2,366 & lebih kecil \\
2 & 2,832 & 2,366 & lebih besar \\
3 & 1,615 & 2,366 & lebih kecil \\
4 & 5,629 & 2,366 & lebih besar \\
5 & 6,182 & 2,366 & lebih besar \\
6 & 4,047 & 2,366 & lebih besar \\
$\vdots$ & $\vdots$ & $\vdots$ & $\vdots$ \\
60 & 3,259 & 2,366 & lebih besar \\
\hline
\end{tabular}

Berdasarkan Tabel 2, dari 60 pengamatan terdapat $\geq 50 \%$ nilai $d_{j}^{2}$ lebih kecil dari nilai $\chi_{3 ; 0,50}^{2}=2,366$. Maka dapat diasumsikan data karakteristik kualitas batik tulis berdistribusi normal.

\subsection{Uji Signifikansi Korelasi}

Data yang digunakan merupakan data multivariat sehingga perlu dilakukan adanya uji korelasi antar variabel. Untuk mengetahui ketiga variabel tersebut berhubungan perlu dilakukan uji signifikansi korelasi variabel menggubkan uji Bartlett.

Hipotesis

$\mathrm{H}_{0}: \mathbf{R}=\mathbf{I}$ (tidak ada korelasi antar variabel)

$\mathrm{H}_{1}: \mathbf{R} \neq \mathbf{I}$ (ada korelasi antar variabel)

Statistik Uji :

$$
\chi_{\text {hitung }}^{2}=-\left\{n-1-\frac{2 p+5}{6}\right\} \ln |\boldsymbol{R}|
$$

$\chi_{\text {hitung }}^{2}=14,81683$

$p$-value $=0,00198$

Pada taraf signifikansi $\alpha=5 \% \mathrm{H}_{0}$ ditolak, karena nilai $\chi_{\text {hitung }}^{2}$ sebesar $14,81683>\chi_{,(0,05 ; 1)}^{2}$ sebesar 3,84 dan $p$-value bernilai $0,00198<\alpha$ sebesar 0,05. Dapat disimpulkan ketiga variabel pada karakteristik kualitas batik tulis terdapat korelasi.

\subsection{Grafik Pengendali MEWMA}

Stabilitas proses merupakan asumsi yang harus dipenuhi sebelum menghitung kemampuan proses multivariat. Proses dikatakan stabil jika seluruh data berada di antara batas-batas pengendali. Pengendalian rata-rata proses dilakukan dengan menggunakan grafik pengendali Multivariate Exponentially Weighted Moving Average (MEWMA). Pada grafik pengendali ini digunakan nilai pembobot $\lambda$ sebesar 0,6. Menurut Montgomery (2009), semakin kecil $\lambda$ akan lebih efektif dalam menddeteksi pergeseran mean proses yang kecil. Semakin besar nilai $\lambda$, semakin besar juga batas pengendali grafik pengendali.

Penerapan grafik pengendali MEWMA menggunakan software Microsoft Excel. Sebelum dilakukan perhitungan, terlebih dahulu data distandarkan sesuai dengan z-score. Dengan nilai awal $Z_{0}=0$ dan $\lambda=0,6$, serta banyaknya pengamatan yang dilakukan adalah 60. Perhitungan nilai $Z_{j}$ dengan persamaan 3. Setelah nilai $Z_{j}$ diperoleh, dilakukan 
perhitungan $\mathrm{T}_{\mathrm{j}}^{2}$ untuk titik yang akan diplotkan dalam grafik pengendali MEWMA dengan persamaan 4.

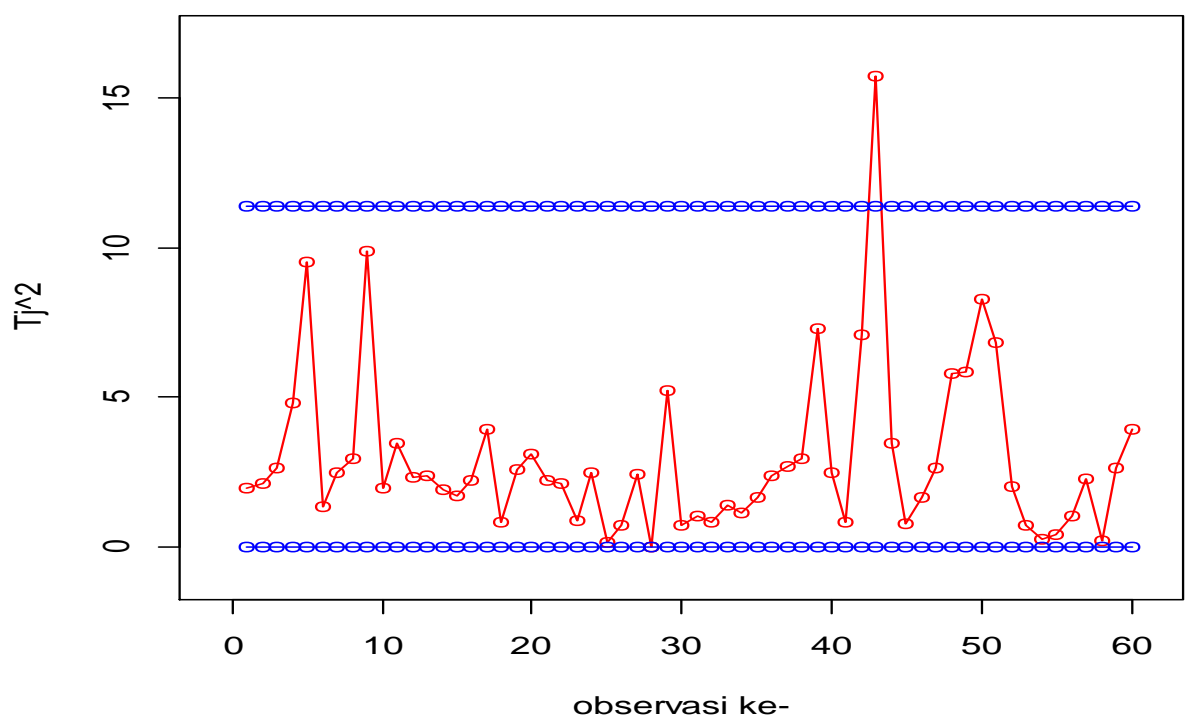

Gambar 1. Grafik Pengendali MEWMA dengan $\lambda=0,6$

Berdasarkan Gambar 1, dapat diketahui bahwa dari 60 sampel data terdapat satu nilai $T_{j}^{2}$ yang keluar dari batas kendali (BKA) dimana besarnya 15,70871 yang menandakan proses produksi tidak terkendali secara statistik. Karena dengan grafik pengendali MEWMA tidak terkendali, maka proses selanjutnya yang memungkinkan agar grafik MEWMA menjadi optimal adalah dengan menggunakan Average Run Length (ARL) dengan pendekatan Rantai Markov.

\subsection{Menentukan Pergese ran Proses}

Perfoma dari sebuah grafik pengendali tergantung pada nilai pergeseran proses yang terjadi. Besarnya nilai pergeseran untuk grafik pengendali MEWMA dapat dihitung dengan persamaan 6. Besarnya pergeseran proses yang dapat diterima, berada dalam interval konfidensi distribusi Student's $t$, yang dapat dihitung berdasarkan persamaan 14, yaitu sebagai berikut:

Untuk variabel pertama, yaitu nilai panjang kain diperoleh $220,2260 \leq \mu_{11} \leq 221,9123$

Untuk variabel kedua, yaitu nilai lebar kain diperoleh $125,3201 \leq \mu_{21} \leq 127,0065$

Untuk variabel ketiga, yaitu nilai waktu pelorotan kain diperoleh $8,8167 \leq \mu_{31} \leq 10,5029$

Pada studi kasus ini, akan diamati satu nilai pergeseran proses. Kasus dianggap bergeser dari

$$
\boldsymbol{\mu}_{\mathbf{0}}=\left[\begin{array}{c}
221,069 \\
126,163 \\
9,659
\end{array}\right] \text { ke } \boldsymbol{\mu}_{\mathbf{1}}=\left[\begin{array}{c}
221,0202 \\
126,4227 \\
111,24
\end{array}\right]
$$

Sehingga berdasarkan persamaan 8 diperoleh nilai pergeseran proses pada penelitian tugas akhir ini sebesar 1,7. Berdasarkan grafik parameter $r$ optimal (Lee dan Khoo, 2005) dengan nilai $\mathrm{ARL}=200$ diperoleh nilai $\mathrm{r}$ optimal untuk penelitian tugas akhir ini adalah $\delta=1,7$. Nilai 1,7 menunjukkan bahwa proses mengalami pergeseran yang kecil dari nilai $\boldsymbol{\mu}_{\mathbf{0}}$. Setelah mendapatkan nilai pergeseran proses, selanjutkan menentukan nilai parameter $\mathrm{r}$ dimana nilai parameter $\mathrm{r}$ didapatkan berdasarkan grafik parameter $\mathrm{r}$ optimal (Lee dan Khoo, 2005). Didapatkan nilai $r$ sebesar 0,28 cara mendapatkannya dengan menjumlahkan nilai $\mathrm{r}$ pada grafik parameter $\mathrm{r}$ optimal dimana pada penelitian tugas akhir ini 
variabel (p) yang digunakan sebanyak 3 maka untuk memperoleh nilai parameter $\mathrm{r}$ digunakan grafik parameter $r$ untuk $p=2$ dan $p=4$ pada nilai ARL 200 dan pergeseran prosesnya sebesar 1,7 kemudian dibagi dua. Sehingga didapatkan nilai parameter $r$ nya sebesar 0,28. Nilai ARL biasanya ditetapkan oleh perusahaan namun pada penelitian tugas akhir ini nilai on target ARL yang digunakan mengikuti rekomendasi dari Runger dan Prabhu (1996) yaitu sebanyak 200.

\subsection{Grafik MEWMA Optimal dengan Pendekatan Rantai Markov}

Dalam perhitungan statistik $\mathrm{T}_{\mathrm{j}}^{2}$ optimal menggunakan bantuan software $\mathrm{R}$ 3.3.3 Nilai statistik $\mathrm{T}_{\mathrm{i}}{ }^{2}$ optimal pada penelitian tugas akhir ini menggunakan nilai pergeseran proses $\delta$ $=1,7$ dan $\mathrm{r}=0,28$ berdasarkan pada perhitungan pada pembahasan sebelumnya. Hasil perhitungannya adalah sebagai berikut:

$$
\mathrm{T}_{\mathrm{j}}^{2}=\left[\begin{array}{c}
0,9521 \\
1,2789 \\
2,3425 \\
\vdots \\
2,6735
\end{array}\right]_{(60 \times 1)}
$$

Berdasarkan perhitungan nilai $\mathrm{T}_{\mathrm{j}}^{2}$ dengan menggunakan ARL pendekatan rantai markov didapat nilai $\mathrm{T}_{\mathrm{j}}^{2}$ yang optimal.

Setelah didapatkan nilai $\mathrm{T}_{\mathrm{j}}^{2}$ optimal, maka disusun grafik pengendalinya, dengan konstanta smoothing $r$ optimal yang telah didapat pada pembahasan sebelumnya dan batas pengendali atas (BKA) grafik diperoleh dari package spc software $\mathrm{R}$ versi 3.3.3 sebesar 12,25353. Grafik pengendali MEWMA optimal berdasarkan ARL dengan pendekatan Rantai Markov ditunjukkan pada Gambar 2:

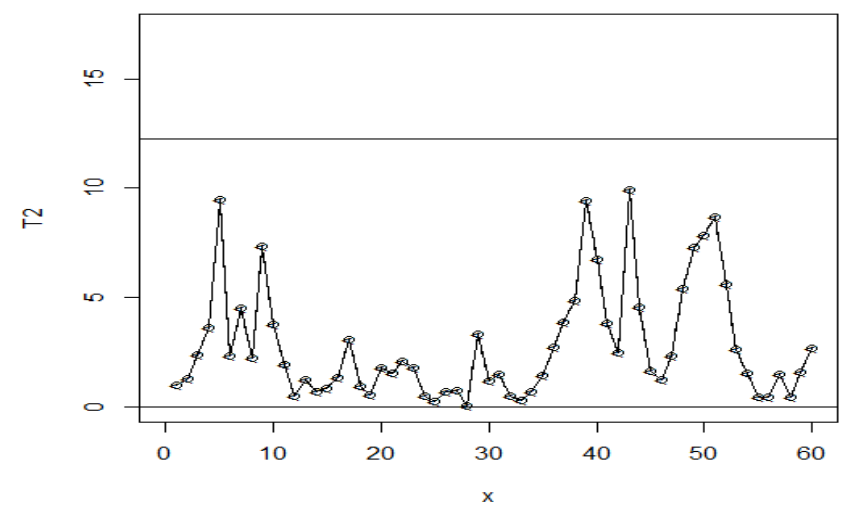

Gambar 2. Grafik Pengendali MEWMA dengan ARL Pendekatan rantai Markov

\subsection{Analisis Kapabilitas Proses Grafik Pengendali MEWMA}

Asumsi yang harus dipenuhi sebelum menghitung kapabilitas proses adalah data berdistribusi normal multivariat dan proses dalam kondisi stabil atau terkendadli secara statistik. Berdasarkan uji stabilitas proses yang ditunjukkan pada Gambar 2 grafik pengendali MEWMA sudah dalam keadaan terkendali, sehingga dapat dilakukan analis is untuk kapabilitas proses multivariat. Tetapi sebelumnya menghitung terlebih dahulu kapabilitas proses univariat berdasarkan persamaan 10 dan 11. Berikut hasil perhitungan kapabilitas proses dari ketiga karakteristik kualitas batik tulis. 
Tabel 3. Kapabilitas proses secara univariat diagram kontrol MEWMA

\begin{tabular}{lll}
\hline Variabel & $\mathrm{C}_{\mathrm{pm}}$ & $\mathrm{C}_{\mathrm{pmk}}$ \\
\hline Panjang Kain $\left(\mathrm{X}_{1}\right)$ & 0,64262 & 0,580884 \\
Lebar Kain $\left(\mathrm{X}_{2}\right)$ & 0,636036 & 0,570588 \\
Waktu Pelorotan Kain $\left(\mathrm{X}_{3}\right)$ & 0,271736 & 0,161948 \\
\hline
\end{tabular}

Berdasarkan hasil analisis secara multivariat didapatkan nilai $\mathrm{MC}_{\mathrm{pm}}$ sebesar 0,516797 dan nilai $\mathrm{MC}_{\mathrm{pmk}}$ sebesar 0,437807, dimana nilai ini lebih kecil dari 1 yang menandakan bahwa secara multivariat kinerja proses memiliki presisi yang kurang baik pada ketiga variabel tersebut. Jadi, dapat disimpulkan bahwa kapabilitas proses produksi batik tulis di Batik Semarang 16, Meteseh menggunakan diagram kontrol MEWMA dengan pendekatan rantai markov belum kapabel, karena proses cenderung mendekati batas spesifikasi bawah.

\section{KESIMPULAN}

Berdasarkan analisis dan pembahasan yang diperoleh pada bab sebelumnya, dapat disimpulkan bahwa grafik pengendali MEWMA merupakan salah satu alat yang digunakan untuk mengontrol rata-rata proses produksi. Penerapan grafik pengendali MEWMA pada data karakteristik kualitas proses produksi batik tulis di Batik Semarang 16, Meteseh menunjukkan bahwa terdapat plot yang berada diluar batas kendali atas (BKA) dengan $\lambda=$ 0,6 yaitu sebesar 15,70871. Karena dengan grafik pengendali MEWMA tidak terkendali, maka proses selanjutnya yang memungkinkan agar grafik MEWMA menjadi optimal adalah dengan menggunakan Average Run Length (ARL) dengan pendekatan Rantai Markov.

Dihasilkan proses terkendali secara statistik dan grafik MEWMA optimal. Nilai kapabilitas proses untuk grafik pengendali Multivariate Exponentially Weighted Moving Average (MEWMA) kurang dari 1, yaitu nilai $\mathrm{MC}_{\mathrm{pm}}$ sebesar 0,516797 dan nilai $\mathrm{MC}_{\mathrm{pmk}}$ sebesar 0,437807 dapat disimpulkan bahwa kapabilitas proses produksi batik tulis di Batik Semarang 16, Meteseh menggunakan diagram kontrol MEWMA dengan pendekatan rantai markov tidak capable, karena proses cenderung mendekati batas spesifikasi bawah.

\section{DAFTAR PUSTAKA}

Ari, W. 2011. Batik Nusantara: Makna Filosofis, Cara Pembuatan, dan Industri Batik. Yogyakarta: ANDI.

Arinda, A., Mustafid, dan Mukid, M.A. 2016. Penerapan Diagram Kontrol Multivariate Exponentially Weighted Moving Average (MEWMA) pada Pengendalian Karakteristik Kualitas Air. Jurnal Gaussian vol. 5, No. 1 : Hal. 31-40.

Assauri, S. 1980. Management Produksi. Fakultas Ekonomi Universitas Indonesia.

Daniel, W. W. 1989. Statistika Nonparametrik Terapan. Diterjemahkan oleh: Alex Tri Kantjono W. Jakarta: PT Gramedia.

Gaspersz, V. 2005. ISO 9001: 200 And Continual Improvement. Jakarta: Gramedia Pustaka Umum.

Handoko, T.H. 1999. Dasar-Dasar manajemen Produksi dan Operasi. Edisi Pertama. Yogyakarta: BPFE.

Jayanti, J. D., Wibawati. 2014. Penerapan Diagram Kontrol Mewma dan Mewmv Pada Pengendalian Kualitas Air Produksi Di Ipam Ngagel I. Jurnal Sains dan Sei Pomits vol. 3, No.2 : Hal. 314-319.

Johnson, R, \& Wichern, D. 2007. Applied Multivariat Statistical Analysis 6th Edition. United States of America: Pearson Education.

Kotler, P. dan Keller, K. L. 2008. Marketing Management 13th edition. United States of America: Pearson Education. 
Lee, M. H. dan M. B. C. Khoo. 2005. Optimal Statistical Design of a Multivariat EWMA Chart based on ARL and MRL. Journal Statistics- Simulations and Computation, 35: 831-847.

Lowry, C. A., Woodall, W. H., Champ, C. W., dan Rigdon, S. E. 1992. A Multivariat Exponentially Weighted Moving Average Control Chart Technometrics 34(1): 46-53.

Marimin, 2005. Teknik dan Aplikasi: Pengambilan Keputusan Kriteria Majemuk. Jakarta: PT Grasindo.

Montgomery, D. C. 2009. Introduction to Statistical Quality Control $6^{\text {th }}$ Edition. United States of America: John \& Wiley Sons, Inc.

Morrison, D. 1990. Multivariat Statistical Methods 3th Edition. New York: Mc Graw Hill Publishing Company.

Raissi, S. 2009. Multivariat Process capability Indices On The Presence of Priority for Quality Characteristics. Journal of Industrial Engeneering international, Vol 5, No. 9, 27-36.

Runger, G. C., Prabhu, S. S. 1996. A Morkov Chain Model for The Multivariat American Statistical Assosiation. 91(436): 1701-1706.

Suryanto. 1988. Metode Statistik Multivariat. Jakarta: P2LPTK. 